\title{
Optimasi Gas Injeksi Pada Sembur Buatan Gas Lift Untuk Meningkatkan Besarnya Laju Produksi Minyak Maksimum Dan Evaluasi penghentian Kegiatan Gas Lift, Pada Lapangan Libo PT. Chevron Pacific Indonesia Duri.
}

\author{
Ali Musnal ${ }^{1}$, Fitrianti $^{2}$ \\ ${ }^{1}$ Program Studi Teknik Perminyakan Universitas Islam Riau
}

\begin{abstract}
Abstrak
Banyak jenis pengangkatan buatan atau " Artificial Lift "yang dapat dipergunakan, antara lain; Gas Lift yaitu pengangkatan buatan dengan mempergunakan gas, dan Pumping yaitu pengangkatan buatan dengan mempergunakan pompa, pemakaian jenis pengangkatan buatan ini tergantung pada kondisi sumur dan lapangan minyak yang akan dikerjakan.

Dengan berjalannya waktu produksi, tekanan reservoir akan mengalami penurunan, hal ini disebabkan meningkatnya laju produksi air.dan berkurangnya tenaga pendorong Gas. Untuk mengatasi hal tersebut diatas dipergunakan pengangkatan buatan yang dikenal dengan "Artificial Lift" .Pada 4 sumur kajian, pengangkatan buatan di pergunakan "Gas Lift" yaitu dengan mempergunakan gas sebagai media pengangkatan minyak.

Pada penelitian ini Peneliti akan menghitung Jumlah Gas injeksi yang optimum untuk mendapatkan laju produksi maksimum dan mengevaluasi kenapa kegiatan gas lift diberhentikan di lapangan Libo ini. Berdasarkan hasil Penelitian dan Perhitungan optimasi, banyak jumlah gas yang melampaui batas optimasi di injeksikan, sehinggah laju produksinya menjadi kecil, hal ini terlihat dari hasil penelitian yang Peneliti lakukan. Bila kelebihan gas injeksi ini tidak terjadi akan dapat mempanjang kegiatan gas lift selama 3 bulan dalam satu tahun. Faktor terhentinya kegiatan gas lift di lapangan Libo, Yaitu menurunya laju produksi gas dari 4 sumur yang ada dari 3.134.609 SCF/D menjadi 2.931.000 SCF/D dan supplay gas yang tidak stabil dari perusahaan pemasok gas.
\end{abstract}

KataKunci: $\quad$ Gas Lift, Optimasi,Evaluasi.

Alamat email korespondensi penulis: ali.musnal@eng.uir.ac.id

\section{PENDAHULUAN}

\section{Latar Belakang}

Untuk memenuhi Kebutuhan bahan bakar minyak (BBM) di Indonesia, Upaya yang dilakukan mencari sumur sumur baru. Mengoptimasikan ladang sumur minyak yang ada dan dapat juga dilakukan menggunakan energi terbarukan seperti biofuel,matahari,angin dan lain sebagainya. Disamping itu pada sumur minyak itu sendiri dilakukan pengangkatan buatan (artificial lift) yaitu pengangkatan minyak yang dilakukan dengan pemompaan dan sembur buatan (Gas Lift). Pada lapangan minyak PT.Chevron Pacifik Indonesia untuk daerah Libo mempergunakan Gas Lift sebagai media pengangkat minyak. Masalah yang terjadi pada lapangan tersebut belum lagi dilakukan optimsi injeksi gas lift Dan hal ini juga merupakan salah faktor penyebab dihentikannya kegiatan gas lift.

Pada penelitian ini jumlah gas optimum yang dinjeksikan ke kedalaman sumur melalui katup injeksi merupakan parameter yang sangat penting dihitung, karena bila gas yang dinjeksikan melampau batas optimum laju produksi bukannya bertambah besar, tetapi sebaliknya akan terjadi penurunan produksi minyak. Setelah melakukan evaluasi maka akan dilakukan studi kelayakan berdasarkan jumlah produksi gas pada lapangan tersebut dan kemungkinan suplai dari lapangan lain selama produksi.

\section{METODOLOGI PENELITIAN}

Metoda dalam penelitian ini dilakukan dengan merujuk ke referensi yang berhubungan dengan permasalahan. Kemudian di aplikasikan pada lapangan sumur minyak. dengan melakukan terjun lansung kelapangan untuk mengumpulkan data-data lapangan, setelah itu memproses data dan mengevaluasi parameter terkait untuk mendapatkan gambaran efisiensi sembur buatan dan lapangan gas lift. 


\section{TINJAUAN PUSTAKA}

Untuk perhitungan Optimasi Gas Injeksi Pada Sembur Buatan Gas Lift dengan menggunakan dua pendekatan dalam penelitian ini, yaitu Kurva IPR Sumur dan sistem gas lift itu sendiri.

\section{Perhitungan Kurva IPR Sumur}

Untuk mengetahui prilaku aliran fluida dari reservoir ke lubang sumur dapat dilihat dari kurva IPR sumur tersebut. Perhitungan kurva IPR di lapangan digunakan metode standing untuk skin $\neq 0$, dan metoda vogel untuk skin $=0$, (Brown, K.E 1984).

Unuk Skin tidak sama dengan Nol $\mathrm{S} \pm 0$, maka membuat kurva IPR dipergunakan persamaan Standing

$$
\text { Pwf' }=\text { Ps }- \text { FE ( Ps }- \text { Pwf })
$$

\section{Laju Alir Maksimum (Qmax)}

$$
\mathrm{Qmax}=\frac{\mathrm{Qo}}{\left(1-0,2 \times\left(\frac{\mathrm{Pwf} \prime}{\mathrm{Ps}}\right)-0,8 \times\left(\frac{\mathrm{Pwf} \prime}{\mathrm{Ps}}\right)^{2}\right)}, \mathrm{BFPD}
$$

Menghitung harga $Q$ untuk setiap Pwf yang berbeda-beda (Pwf asumsi)

$$
\mathrm{Qo}=\operatorname{Qmax} \times\left(1-0,2 \times\left(\frac{\mathrm{Pwf} \prime}{\mathrm{Ps}}\right)-0,8 \times\left(\frac{\mathrm{Pwf} \prime}{\mathrm{Ps}}\right)^{2}\right), \mathrm{BOPD}
$$

\section{SISTEM GAS LIFT}

Sembur buatan adalah suatu mekanik pengangkatan cairan dr dasar sumur ke permukaan dimana gas dengan tekanan relative tinggi (250Psi) digunakan sebagai media pengangkat.

Tujuan dari injeksi gas sebagai pengangkatan buatan :

1. Mengurangi gradient tekanan aliran dalam tubing dengan menambahkan gas pada tubing, dalam pengertian gas yang tercampur dengan fluida formasi dapat meringankan beban diatas katup injeksi

2. Membentuk kolom gas dalam tubing yang akan mendorong kolom fluida dalam tubing naik kepermukaan Sebagai akibat mengurangi densitas fluida, sehingga memungkinkan tekanan reservoir mampu mendorong fluida produksi ke permukaan.

Pada gambar 1 dibawah ini dapat dilihat system sumur gas lift atau sembur buatan

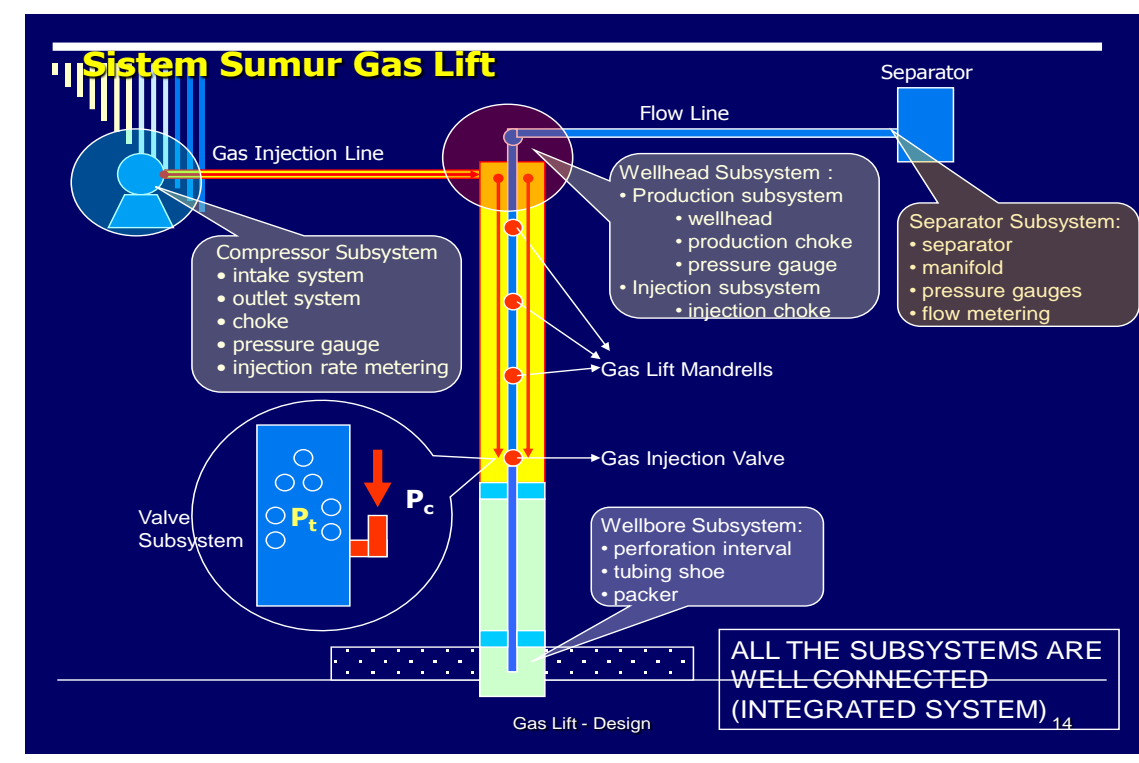

Gambar 1. Sistem Sumur Gas Lift 
DATA DAN PERHITUNGAN

Tabel 1. Data Sumur X1

\begin{tabular}{ccc}
\hline KOMPONEN & SATUAN & UKURAN \\
\hline Kedalaman Sumur & $\mathrm{ft}$ & 6000 \\
\hline Laju produksi & $\mathrm{bpd}$ & 492 \\
\hline Kadar air & $\%$ & 95 \\
\hline Tekanan Kepala Sumur & Psi & 150 \\
\hline Ukuran tubing & $\mathrm{In}$ OD & 2 \\
\hline Tekanan alir dasar sumur & Psi & 1800 \\
\hline Tekanan injeksi gas & Psi & 900 \\
\hline Tekanan kick off & Psi & 950 \\
\hline Gradian Tekanan kill fluid & Psi/ft & 0.5 \\
\hline Tekanan statik reservoir & Psi & 2400 \\
\hline Bracketing envelope & $\%$ & 10 \\
\hline GLR formasi & Scf/stb & 300 \\
\hline SG gas yang diinjeksikan & - & 0.70 \\
\hline Tempratur dasar sumur & ${ }^{0} \mathrm{~F}$ & 200 \\
\hline Fow efisiensi & - & 2 \\
\hline
\end{tabular}

\section{Perhitungan Kemampuan Sumur}

Untuk mengetahui kemampuan suatu sumur untuk berproduksi dapat dilihat dari kurva IPR sumur tersebut. Untuk perhitungan kurva IPR di lapangan digunakan metode Standing Langkah-langkah perhitungan Pembuatan kurva IPR sumur X1 :

Untuk Skin tidak sama dengan Nol $\mathrm{S} \pm 0$, maka persama untuk membuat kurva IPR dipergunakan persamaan Sanding :

$$
\mathrm{Pwf}^{\prime \prime}=2400-2(2400-1800)=1200 \mathrm{Psi}
$$

besarnya laju alir maksimum (Qmax)

$$
\begin{aligned}
\text { Qmax } & =\frac{\text { Qtest }}{\left(1-0,2 \times\left(\frac{\mathrm{Pwf}}{\mathrm{Ps}}\right)\right)-0,8 \times\left(\frac{\mathrm{Pwf}}{\mathrm{Ps}}\right)^{2}} \\
& =\frac{492}{\left(1-0,2 \times\left(\frac{1200}{2400}\right)\right)-0,8 \times\left(\frac{1200}{2400}\right)^{2}}=702.85 \mathrm{BPD}
\end{aligned}
$$

\section{harga Q untuk setiap Pwf yang berbeda-beda (Pwf asumsi)}

$$
\mathrm{Qo}=\mathrm{Qmax} \times\left(1-0,2 \times\left(\frac{\mathrm{Pwf}}{\mathrm{Ps}}\right)\right)-0,8 \times\left(\frac{\mathrm{Pwf}}{\mathrm{Ps}}\right)^{2}
$$

Dengan rumus tersebut diatas didapat harga Q untuk setiap Pwf yang diasumsikan. 
Tabel 2. Penentuan Laju Produksi untuk Berbagai Harga Pwf pada Sumur X1

\begin{tabular}{ccc}
\hline Pwf (Psi) & Pwf '(Psi) & Qo (BFPD) \\
\hline 1200 & 0 & 702.85 \\
\hline 1400 & 400 & 667,71 \\
\hline 1600 & 800 & 604,45 \\
\hline 1800 & 1200 & 492,00 \\
\hline 2000 & 1600 & 365,48 \\
\hline 2200 & 2000 & 203,83 \\
\hline 2400 & 2400 & 0 \\
\hline
\end{tabular}

Selanjutnya dengan membuat plot antara harga Q vs Pwf akan didapat kurva IPR sebagai berikut:

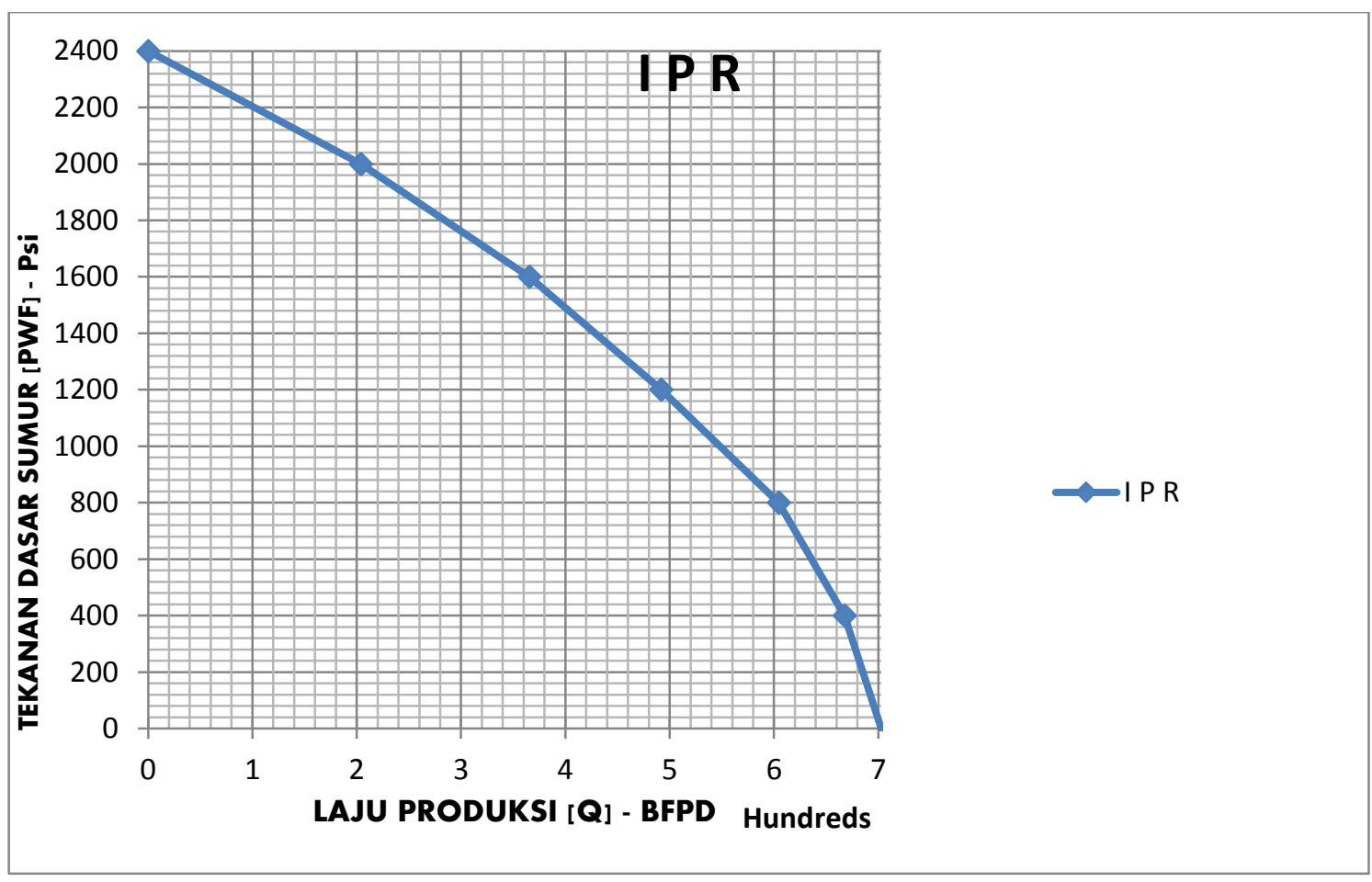

Gambar 2. Kurva IPR Sumur X1

\section{Kedalaman Titik Injeksi}

Pada dasarnya makin besar tekanan gas yang diinjeksikan akan makin dalam letak titik injeksinya, sehingga akan memperbesar draw down tekanan dan laju produksi

Prosedur Perhitungan :

1. Buat sumbu kartesian pada kertas transparan (lihat Gambar 3) yang sesuai dengan skala pressure traverse pada Gambar 3.

2. Hitung besarnya tekanan alir dasar sumur ( Pwf ), sdh diketahui $=1800$ Psi

3. Tarik garis datar pada kedalaman $6000 \mathrm{ft}$ dan Plot titik $(1800,6000)$

4. Gambar 4 adalah pressure traverse yang sesuai dengan kondisi yang diminta, yaitu $q L=700 \mathrm{STB} / \mathrm{hari}$, dan $d t=2 "$

5. Pilih garis gradien aliran untuk $G L R=300 \mathrm{SCF} / \mathrm{STB}$, sesuai dengan GLR dari formasi.

6. Tentukan kedalaman ekivalen $P w f=1800$ psi, Lihat Gambar 4.

7. Tempatkan titik $(1800,6000)$ di kertas transparan di atas titik kedalaman ekivalen Pwf $=1800$ psi 
8. Jiplak kurva gradien aliran pada $G L R=300 \mathrm{SCF} / \mathrm{STB}$.

9. Untuk $\gamma g i=0.70$ dan $P s o=900 \mathrm{psi}$, untuk menentukan gradien tekanan gas, darimana diperoleh harga $23.6 \mathrm{psi} / 1000 \mathrm{ft}$.

Temperatur rata - rata $=\frac{120+200}{2}+460=620 o R=\frac{100+\left\{70+\left(\frac{1.6 \times 6000}{100}\right)\right\}}{2 !}+460=590 \mathrm{R}$

Gradian tekanan gas setelah dikoreksi $=23.6 \times \frac{590}{620}=22.42 \mathrm{Psi} / \mathrm{ft}$

10. Pada kedalaman $6000 \mathrm{ft}$, tekanan gas dalam annulus adalah :

$\mathrm{P} 6000=900+6000(22.42) / 1000=1034.52$ psi.

11. Plot titik $(1034.52,6000)$

12. Hubungan titik $(900,0)$ dengan titik $(1034,52,6000)$ Garis ini memotong kurva gradien aliran di titik.dilangkah 9. ( 1100., 5000 ).

13. Titik injeksi ditentukan dengan menelusuri dari titik potong langkah 13 sejarak 50 Psi. Koordinat titik injeksi adalah $(945,4450)$.

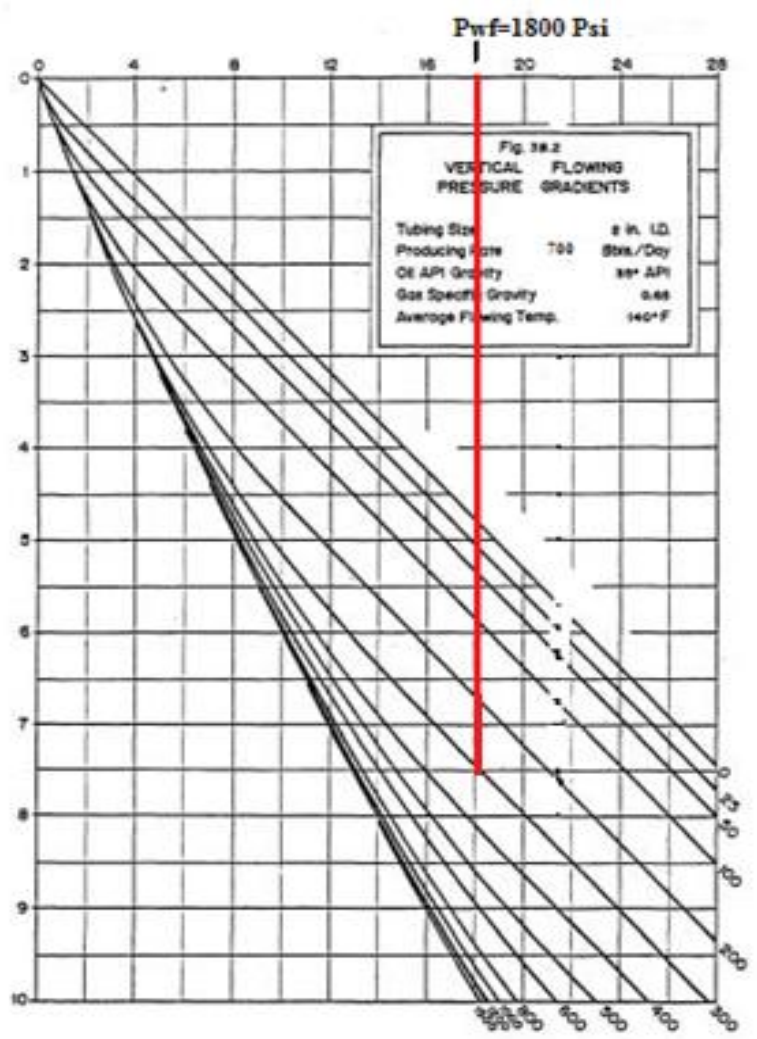

Gambar 3. Kedalaman Eqivalen Pada Garfik Pressure Traverse 


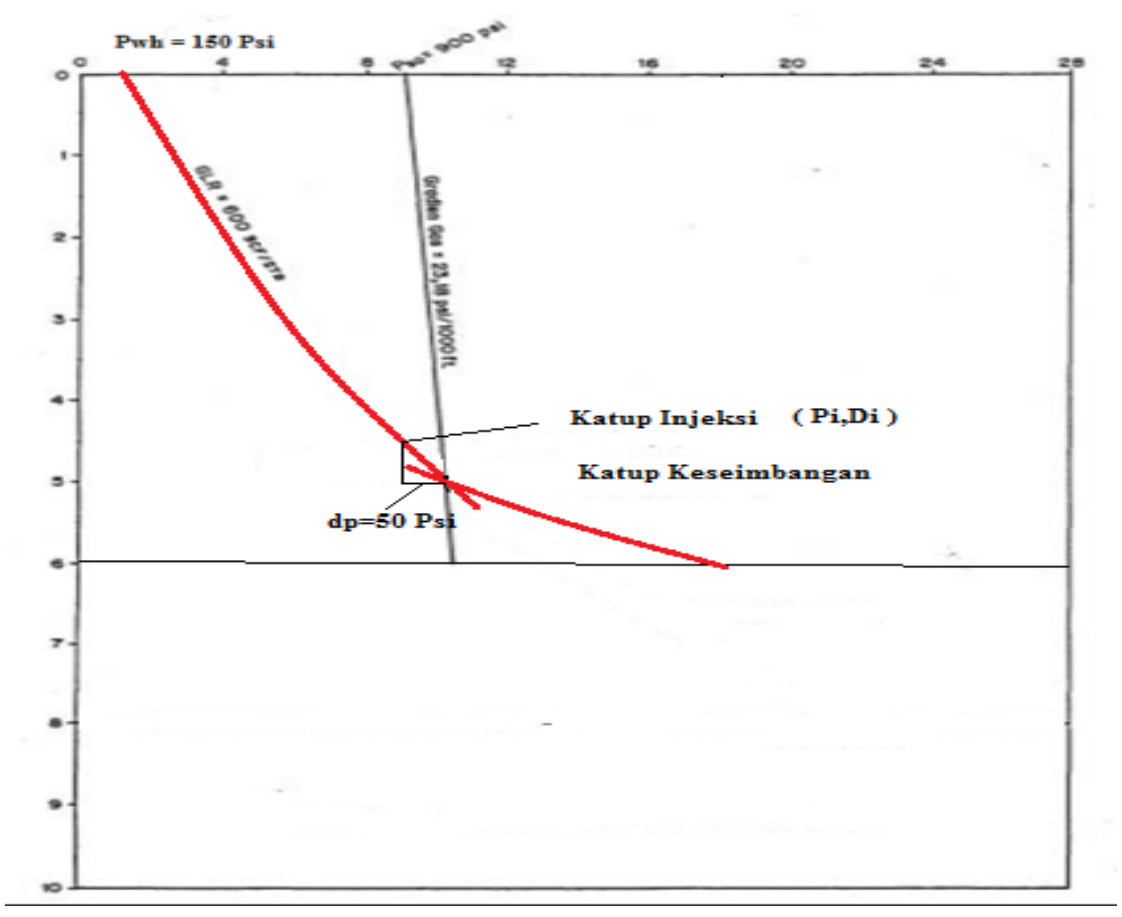

Gambar 4. Kedalaman Katup Injeksi

\section{Penentuan Jumlah Gas Injeksi}

1. Plot titik $(150,0)$, di mana $P w h=150$ psi

2. Dengan menggeser kertas transparan ke atas / ke bawah diperoleh garis gradien aliran dengan $G L R=900 \mathrm{SCF} / \mathrm{STB}$, yang melalui titik-titik $(945,4450)$ dan $(150,0)$.

3. Jiplak kurva gradien aliran dengan $G L R=900 \mathrm{SCF} / \mathrm{STB}$ tersebut (Lihat Gambar 4).

4. Gas injeksi yang diperoleh adalah : $Q g i=492(900-300)=295.200 \mathrm{SCF} / \mathrm{D}$

5. Qgi pada temperatur titik injeksi adalah :

Tpoi $=120+\left[\frac{200-120}{6000} \times 4450\right]+460=639 R$

Coor $=0.0544 \times[0.70 \times 639]=1.15$

Gas injeksi terkoreksi $=295.200 \times 1.15=339.480$ SCF/D.

\section{Penentuan Kedalaman Katup Unloading}

1. Jarak maksimum antara katup disekitar titik injeksi.

$$
\Delta D v=100 / 0.40=250 \mathrm{ft}
$$

2. Gambar desain tubing line sebagai berikut :

$$
P 1=P w h+0.20 \text { Pso }=150+0.20(900)=320 \mathrm{psi}
$$

$P 2=P w h+200=150+200=350$ psi

$P 2>P 1$, maka $P 2$ dipilih untuk membuat garis tersebut.

Hubungkan titik-titik $(350,0)$ dan $(945,4450)$.garis ini disebut garis perencanaan tubing

3. Specific Gravity gas injeksi $=0.70$ dan $P k o=P s o+\Delta P d=900+100=1000$ psi

Dari Gambar, diperoleh : Gradien tekanan gas $=26.2 \mathrm{psi} / 1000 \mathrm{ft}$

Gradian tekanan gas setelah dikoreksi $=26.2 \times \frac{590}{620}=24.93 \mathrm{Psi} / \mathrm{ft}$

4. 4. Pada kedalaman $6.000 \mathrm{ft}$, tekanan gas : $\quad \mathrm{P} 6000=1000+24.93 \times(6000 / 1000)=1149.58$ Psi

5. Plot titik $(900,0)$ dan buat garis sejajar dengan garis dari Pko.dan Gradien statik $=0.40 \mathrm{psi} / \mathrm{ft}$. Pada kedalaman $1000 \mathrm{ft}$, tekanan statik dalam tubing $=100+0.40(1000)=500$ psi.

6. Hubungkan titik $(150,0)$ dan $(500,1000)$ sampai memotong garis gradien tekanan gas Pko Mulai dari titik potong ini telusuri garis tersebut ke atas sejajar 50 psi dan diperoleh koordinat katup 
unloading sebagai berikut: $D V 1=(1500,440), D V 2=(590,2200)$ $(825,3950), D V 4=(780,3480), D V 3=(620,2900)$

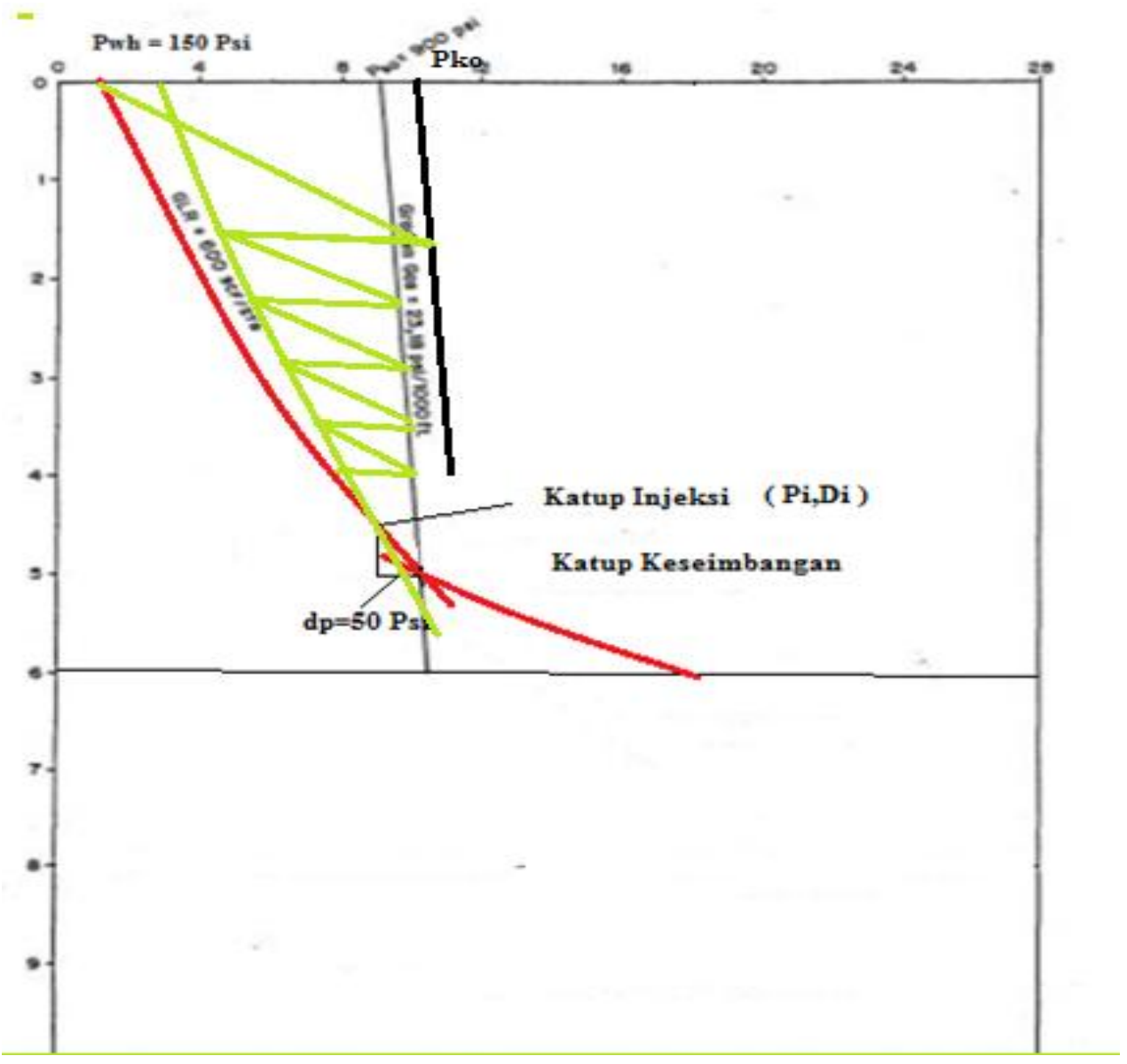

Gambar 5 Kedalaman Katup Unloading

\section{Penentuan letak katup di daerah "bracketing envelope".}

a. Plot titik $(900-100,0)$ atau $(800,0)$ dan buat sejajar dengan garis gradien gas dari Pso $=900$ psi.

b. Perpanjang garis tersebut hingga memotong garis gradien tekanan aliran dalam tubing, Perpotongan tersebut di titik. $(1100,5000)$. Untuk \% bracketing envelope $=10 \%, P a a=$ $(1+0.10)(1100)=1210$ psi $d a n P b b=(1-0,10)(910)=990$ psi, $P a=(1+0,10)(150)=165$ psi dan $P b=(1-0,10)(100)=135$ psi

c. e. Hubungkan titik-titik (Pa) dengan (Paa); garis ini memotong garis gradien tekanan gas . Titik ini adalah batas atas dari pada bracketing envelope, pada kedalaman $3500 \mathrm{ft}$. Hubungkan titik-titik $(\mathrm{Pb})$ dengan $(\mathrm{Pbb})$ dan diperoleh batas bawah, bracketing envelope pada kedalaman $5500 \mathrm{ft}$

d. f. Katup-katup di bracketing envelope dapat dipasang pada kedalaman-kedalaman : 3750, 4000, 4250, 5250, 5000 dan $4750 \mathrm{ft}$. 


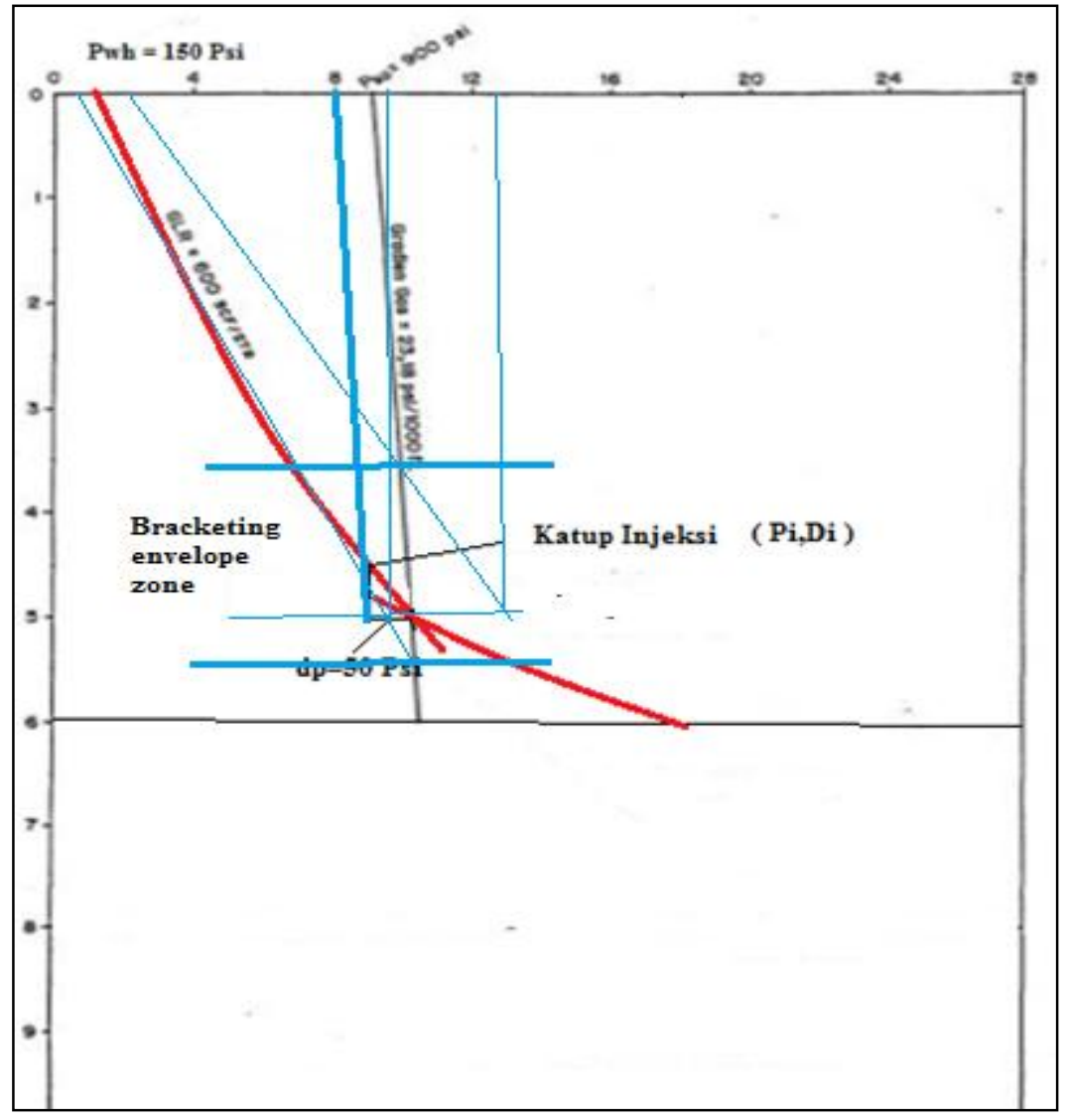

Gambar 6. Bracketing envelope zone

\section{Optimasi Gas Injeksi Sebagai Gas Lift :}

Perpotongan kurva tubing intake untuk masing masing Gas Liquid Ratio ( GLR) dengan kurva IPR, akan menghasilkan besarnya laju alir untuk setiap Gas Liquid Ratio (GLR), lihat grafik dan tabel dibawah ini :

Tabel 2. Penentuan GLR Optimum

\begin{tabular}{llcccccc}
\hline $\begin{array}{l}\text { LAJU ALIR } \\
\text { (BFPD) }\end{array}$ & \multicolumn{7}{c}{ GAS LIQUID RATIO (GLR), SCF/STB } \\
\cline { 2 - 9 } & $\mathbf{2 0 0}$ & $\mathbf{3 0 0}$ & $\mathbf{4 0 0}$ & $\mathbf{5 0 0}$ & $\mathbf{6 0 0}$ & $\mathbf{8 0 0}$ & $\mathbf{1 0 0 0}$ \\
\hline 200 & 1345 & 1200 & 991 & 843 & 747 & 613 & 532 \\
\hline 300 & 1449 & 1300 & 1104 & 976 & 824 & 747 & 650 \\
\hline 400 & 1594 & 1450 & 1256 & 1067 & 993 & 898 & 820 \\
\hline 500 & 1730 & 1620 & 1425 & 1210 & 1146 & 1045 & 1056 \\
\hline 600 & 1856 & 1810 & 1620 & 1376 & 1310 & 1210 & 1310 \\
\hline
\end{tabular}




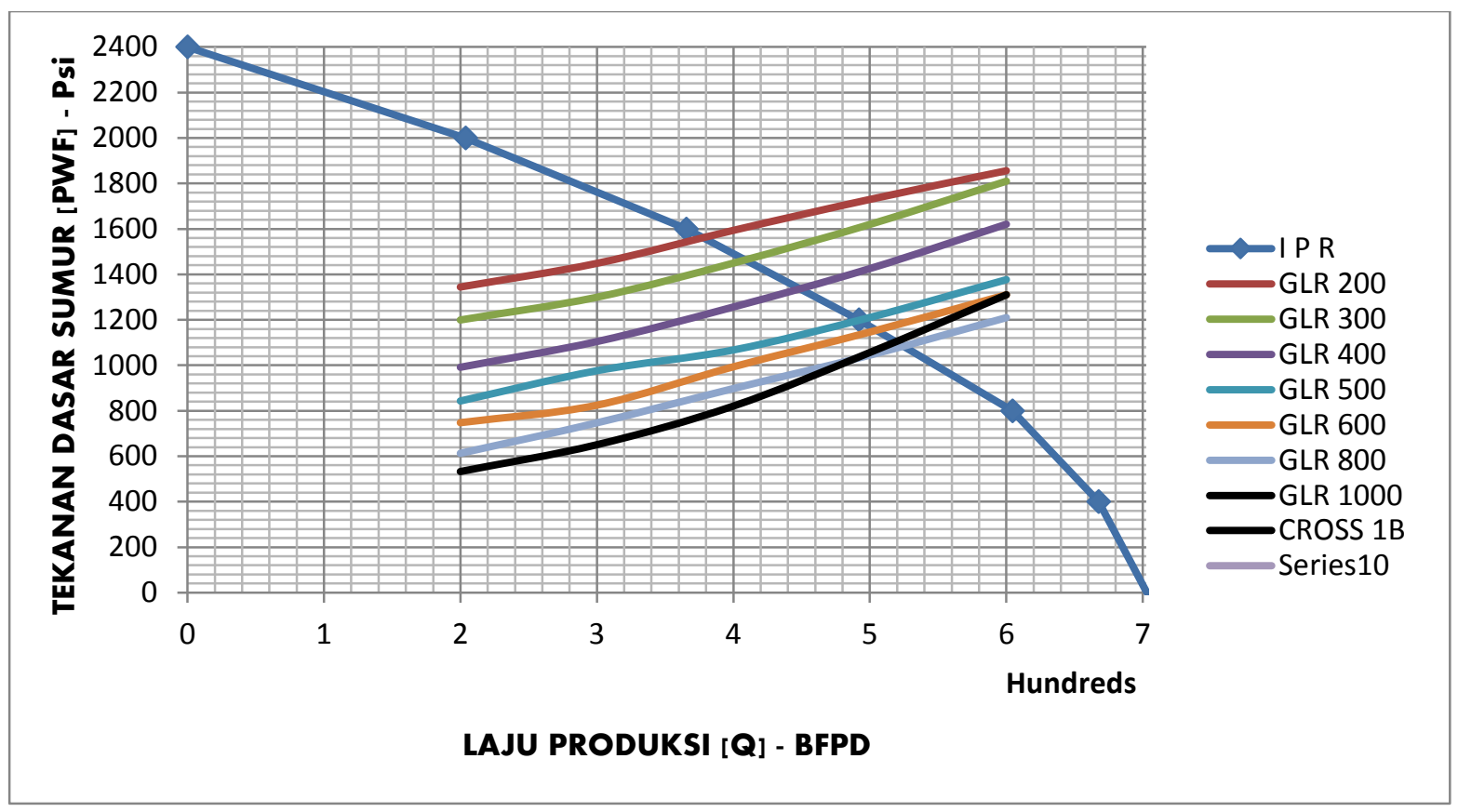

Gambar 7. Perpotongan IPR Dengan masing masing GLR

Tabel 3. Hasil Perpotongan GLR Dengan Laju Alir

\begin{tabular}{cc}
\hline GLR (scf/stb) & $\begin{array}{c}\text { LAJU PRODUKSI } \\
\text { (BPD) }\end{array}$ \\
\hline 200 & 380 \\
\hline 300 & 410 \\
\hline 400 & 445 \\
\hline 500 & 490 \\
\hline 600 & 510 \\
\hline 800 & 530 \\
\hline 1000 & 518 \\
\hline
\end{tabular}




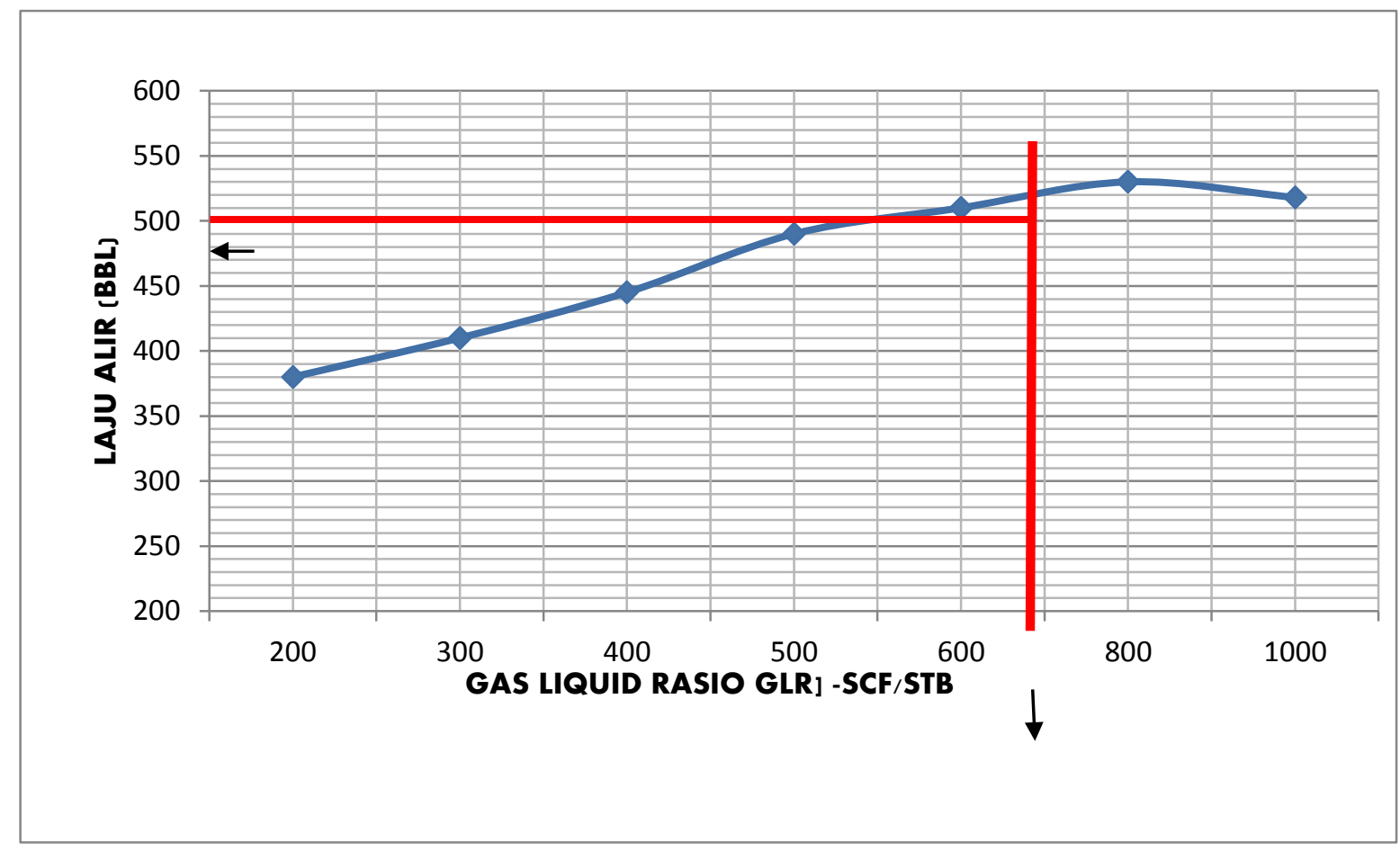

Gambar 8. Jumlah GLR Optimum

Gambar 8 menunjukkan garis plot berwarna merah adalah besarnya jumlah GLR optimum sebesar 800 scf/stb, dimana pada kondisi tersebut didapatkan laju produksi yang maksimum sebesar 530 BPD. Besarnya laju injeksi gas optimum :

$$
\text { Qgi }=530 \mathrm{Stb} / \mathrm{d}(800 \mathrm{scf} / \mathrm{stb}-300 \mathrm{scf} / \mathrm{stb}) \text { Qgi }=265.000 \mathrm{scf} / \mathrm{d}
$$

Dengan cara perhitungan yang sama untuk sumur yang lain diperoleh hasil seperti pada tabel dibawah ini :

Tabel 4. Jumlah Gas Optimum Untuk Masing Masing Sumur

\begin{tabular}{ccccc}
\hline SUMUR & $\begin{array}{c}\text { Qgi OPTIMUM } \\
\text { (SCF/STB) }\end{array}$ & $\begin{array}{c}\text { LAJU } \\
\text { PRODUKSI } \\
\text { (BFPD) }\end{array}$ & $\begin{array}{c}\text { Qgi Actual } \\
\text { (SCF/STB) }\end{array}$ & $\begin{array}{c}\text { LAJU } \\
\text { PRODUKSI } \\
\text { (BFPD) }\end{array}$ \\
\hline $\mathrm{X} 1$ & 265.000 & 530 & 339.480 & 492 \\
\hline $\mathrm{X} 2$ & 300.000 & 1500 & 350.000 & 500 \\
\hline $\mathrm{X} 3$ & 193.000 & 386 & 231.600 & 386 \\
\hline $\mathrm{X} 4$ & 56.000 & 280 & 100.000 & 250 \\
\hline
\end{tabular}

\section{PEMBAHASAN}

Berdasarkan tinjauan Peneliti kelapangan Libo, kegiatan pengangkatan buatan dengan menggunakan gas lift sudah tidak dilakukan lagi, hal ini disebabkan beberapa faktor :

Ada beberapa faktor kenapa Gas lift dihentikan di libo area :

1. Tidak adanya optimasi didalam pemakaian gas lift, Jumlah gas yang dinjeksikan setiap harinya 1.021.080 SCF, dengan besarnya lajur produksi 1628 BFPD

2. Berdasarkan Perhitungan Peneliti, apa bila dilakukan Optimasi Gas Lift akan terjadi pengurangan gas yang diinjeksikan sebesar 207.080 SCF/D, dan penambahan jumlah produksi 1072 BFPD. Selesih angka hasil penelitian dan actual dilapangan cukup segnifikan. 
3. Berdasarkan hasil penelitian tersebut setiap tahunnya dapat menghemat pemakaian jumlah gas dalam arti kata dapat menambah lamanya operasi kurang lebih 3 bulan setiap tahun. Hal ini merupakan salah satu faktor terhentinya kegiatan gas lift.

4. Faktor lainnya adalah kurangnya pasokan gas yang tersedia ,karena produksi gas di PT. CPI tidak memadai. Di Perusahaan Chevron sendiri pasokan gas saat ini masih membeli dari perusahaan lain seperti Perusahaan Conocohilips - Jambi, untuk memenuhi kebutuhan gas di PT.Chevron Pasific Indonesia. Berapa besarnya jumlah gas yang disupplay peneliti tidak mendapatkan datanya.

5. Penggunaan gas yang utama di PT. Chevron Pasific Indonesia adalah pasokan listrik.

Dari perencanaan awal gas lift, PT CPI sudah menyadari hal ini, tapi karena GOR tinggi dan sering terjadi Gassy, maka yang baik dilakukan untuk pengangkatan buatan adalah gas lift. Berdasarkan pengamatan dan hasil perhitungan Peneliti, apabila dilakukan optimasi gas untuk mendapatkan laju produksi maksimal, maka gas lift dapat bertahan dalam jangka waktu yang lebih panjang lagi. Pada tabel dibawah ini dapat dilihat hasil perhitungan optimasi gas lift dan actual pemakain gas injeksi dilapangan

Tabel 5. Hasil Perhitungan Dan Kondisi Real Di lapangan.

\begin{tabular}{ccccc}
\hline SUMUR & $\begin{array}{c}\text { Qgi OPTIMUM } \\
\text { (SCF/D) }\end{array}$ & $\begin{array}{c}\text { LAJU PRODUKSI } \\
\text { (BFPD) }\end{array}$ & $\begin{array}{c}\text { Qgi Actual } \\
\text { (SCF/D) }\end{array}$ & $\begin{array}{c}\text { LAJU PRODUKSI } \\
\text { (BFPD) }\end{array}$ \\
\hline $\mathbf{X 1}$ & 265.000 & 530 & 339.480 & 492 \\
\hline $\mathbf{X} 2$ & 300.000 & 1500 & 350.000 & 500 \\
\hline $\mathbf{X 3}$ & 193.000 & 380 & 231.600 & 386 \\
\hline $\mathbf{X 4}$ & 56.000 & 280 & 100.000 & 250 \\
\hline Total & 814.000 & 2690 & 1.021 .080 & 1628 \\
\hline
\end{tabular}

Pada sumur X1, penghematan gas yang terjadi dalam setiap harinya 74.480 SCF/D, dan kenaikan laju produksi didapat $38 \mathrm{BFPD}$.

Pada sumur X2, penghematan gas yang terjadi dalam setiap harinya 50.000 SCF/D, dan kenaikan laju produksi didapat 1000 . BFPD, kenaikan laju produksi ini sangat menakjutkan sekali karena jumlah gas yang dinjeksikan pada sumur X2 sangat besar dibandingkan 3 sumur gas lift yang ada.

Pada sumur X3, penghematan gas yang terjadi dalam setiap harinya 38.000 SCF/D, dan tidak ada kenaikan lajur produksi.

Pada sumur X4, penghematan gas yang terjadi dalam setiap harinya 44.000 SCF/D, dan kenaikan lajur produksi didapat $30 \mathrm{BFPD}$.

Berdasarkan hasil penelitian ini optimasi gas lift sangat penting sekali, disamping dapat menghemat gas injeksi juga dapat memaksimalkan laju produksi. Terjadi penghematan gas injeksi setiap harinya untuk ke empat sumur sebesar 207.080 SCF/D. Bila diambil dalam jangka 1 tahun atau 360 hari operasi, maka penghematan gas satu tahun sebesar 74.548.800 SCF. Jumlah gas sebesar ini bila dibagi dengan pemakaian gas optimasi setiap harinya, akan terjadi perpanjangan kegiatan gas lift selama 3 bulan setiap tahunnya. dengan kenaikan laju produkksi sebesar 382.320 BFPD.

Faktor yang mempengaruhi dihentikan kegiatan gas lift, yaitu menurunnya produksi gas di lapangan Libo seperti di Libo SE 53 tahun 2000 produksi gas nya 3.134.609 SCF/D dan pada tahun 2008 produksi gas menurun menjadi 2.931.000 SCF/D. Kemudian supplai gas dari perusahaan seperti Perusahaan Conocohilips - Jambi tidak stabil dan tidak memadai 


\section{KESIMPULAN}

Berdasarkan hasil kunjungan lapangan dan hasil perhitungan optimasi gas lift untuk pengangkatan buatan gas lift di Libo, dapat disimpulkan sebagai berikut :

1. Hasil perhitungan besarnya laju injeksi gas optimum dan besarnya laju produksi maksimum setiap sumur dapat dilihat pada tabel 5 .

2. Hasil analisis perhitungan dengan actual dilapangan bila dilakukan optimasi gas akan terjadi penghematan pemakaian gas untuk ke empat sumur sebesar 207.080 SCF/D, dan kenaikan laju produksi sebesar 382.320 BFPD.

3. Berdasarkan hasil evaluasi Peneliti ada beberapa faktor penyebab dihentikan kegiatan Gas Lift, yaitu Faktor yaitu menurunnya produksi gas di lapangan Libo seperti di Libo SE 53 tahun 2000 produksi gas nya 3.134.609 SCF/D dan pada tahun 2008 produksi gas menurun menjadi 2.931.000 SCF/D. Kemudian supplai gas dari perusahaan seperti Perusahaan Conocohilips Jambi tidak stabil dan tidak memadai. Disamping itu tidak adanya optimasi gas injeksi yang sangat siknifikan sekali dalam kelangsungan kegiatan gas lift.

4. Berdasarkan hasil perhitungan keuntungan diadakan optimasi injeksi gas lift akan terjadi penambahan waktu operasi 3 bulan dalam jangka waktu 1 tahun. Hal ini tentunya akan dapat memperpanjang kegiatan pengangkatan buatan gas lift.

\section{DAFTAR PUSTAKA}

American Petroleum Institute " Gas Lift Book 6 Of The Vocational Training Series", 1994

Aditya Ricky Fandi “ Metoda Gas Lift Untuk Sumur Minyak Tua” ITBG 22 April 2016

Brown, K.E., 1977, “The Technology of Artificial Lift Methods”, volume 1, Penn Well Publishing Co., Tulsa, Oklahoma.

Brown, K.E., 1980 “The Technology of Artificial Lift Methods”, volume 2B, Penn Well Publishing Co., Tulsa, Oklahoma.

Brown, K.E 1984 “The Technology of Artificial Lift Methods", volume 4, Penn Well Publishing Co., Tulsa, Oklahoma.

Daniel Hill. "Petroleum Production Sistems"

Hernandez, Ali, 2016, "Fundamentals of Gas Lift Engineering Well Design and Troubleshooting" Gulf Professional Publishing is an Imprint of Elsevier, Cambridge, USA.

Mitra, Niladri Kumar., Kumar Adesh, 2012, "Principles of Artificial Lift", Allied Publisher Pvt. Ltd. New Delhi, India

Pertamina “Pedoman Kerja Teknik Reservoir Dan teknik Produksi’ tahun 2010

Pujo Soekarno “Alokasi Injeksi Gas Untuk Peningkata Produksi Dengan Metoda Proyeksi Gradiant Reson's" Reseach tahun 2013

Pirson., “ Oil Reservoir Engineering” Tahun 1992

Pedoman Kerja Pertamina, “Perencanaan Instalasi Sembur Buatan Kontinyu” tahun 2002.

Sukarno, Pudjo, DR., 1990, "Production Optimalization with Nodal System Analysis”, PT. Indrilco Sakti, Jakarta.

Nobuo Niky Soury ' Gas Alokation Optimization Fopr Continous Flow Gas Lift Systems “ Jepang thn 2013. 